\title{
Factors Influencing Construction Clients'/Contractors' Choice of Subcontractors in Nigeria
}

\author{
Fagbenle, Olabosipo I. \\ Department Building Technology \\ Covenant University, Ota, Ogun State, Nigeria \\ E-mail: olafagbenle@yahoo.com \\ Makinde, Felix A. \\ Department of Building Technology \\ Osun State College of Technology, Esa Oke, Nigeria
}

Oluwunmi, Adedamola O. (Corresponding author)

Department of Estate Management

Covenant University, Ota, Ogun State, Nigeria

E-mail: damilive@luxmail.com

Received: November 13, 2010

Accepted: January 5, 2011

doi:10.5539/jsd.v4n2p254

\begin{abstract}
Arising from the recent shift in the attitude of main contractors to subcontract procurement in some of the developing countries of the world, this study presents the findings of the importance of factors influencing the choice of subcontractors by the clients and contractors. With a focus on three commercial nerve centres of Nigeria (Lagos, Abuja and Port Harcourt), the study presents the findings of a survey of construction clients/contractors and rank the factors they consider in the selection of suitable subcontractors for project execution. The results of the relative index ranking technique indicate that five most important factors are: subcontractors' past experience in terms of size and type of projects completed; subcontractors' management resource in terms of formal and informal training; other related issues in terms of nature of contract and time of the year (weather), past relationships with the clients/contractors (past performance), and project facilitation in terms on labour/plant resources. It is concluded that greatest premiums should be attached to some of these factors for improved construction sustainability.
\end{abstract}

Keywords: Choice, Clients, Construction, Contractors, factors, Improvement, Nigeria Project, Subcontractors

\section{Introduction}

The main contractors are continuously involved in a process of transforming inputs (i.e. materials, labour and capital) into outputs such as constructed facility but usually, they are not in isolation in this long transformation. They are accompanied by subcontractors, equipment dealers and financial institutions among other firms. Lee (1991) indicated that the use of subcontractors in the local industry is prevalent and it is very common for the main contractors to engage subcontractors for most, if not all, of the trades, especially for those trades which require special skills and are specialized in nature and the likes.

Subcontractors play a vital role in the construction industry. For example, Oliver (1997) discovered that main contractors conduct transactions with subcontractors for a number of reasons but it is commonly argued that unstable conditions is one of the overriding reasons since the subcontracting out work packages enables main contractors to be flexible in responding to potential market's ups and downs. Kale and Ardit (2001) opined that unstable demands and seasonality cause construction firms to split into autonomous units and to rely on subcontractors to undertake some of the work packages. Similarly, Beardsworth et al. (1988) reported that construction firms prefer to be flexible rather than maintaining a large organization to undertake the entire construction process. Also, the International Labour Organization (2003) posited that the growth in the practice of outsourcing labour has allowed large companies to effectively divorce themselves from the physical work of construction and concentrate on service functions. Buttressing this assertion, Bresnen et al. (1985) observed that many subcontracting is as a response to the peculiar feature of construction, including the nature of the contracted item, uncertainties and discontinuities in workload as well as the multitude of inter-related tasks which change from stage to stage.

It is also commonly agreed among researchers that clients' needs are generally in terms of time, cost and quality and usually, project success is measured on these terms. According to Chang and Ive (2002), clients, in which category they belong to, would have identified some needs necessitating the client to make a decision to invest in 
construction. These needs influence a client's choice to adopt a particular procurement for his project. Ojo (2009) identified eight important factors affecting clients' choice as speed, price certainty, flexibility, quality standard, complexity, risk allocation, price competition and single point of responsibility. NEDO (1985) further grouped these factors to include cost certainty, time certainty, complexity as well as dispute and arbitration. Dissanayaka (1998) identified thirty-eight selection criteria which are hinged on the prevailing condition of Hong Kong construction industry. These thirty-eight potential selection criteria were then reduced to eleven by Kumaraswamy (1999) in a further research work. Chan et al. (2001) also identified twenty-three selection criteria which were later reduced to fourteen. These include availability of competent contractors and subcontractors, ability to state clear end user's requirements, clients' involvement, size of project and familiarity among others. Holt et al. (1994) examined the client's selection methods of contractors and identified four main areas of weakness. These are: (1) Lack of universal approach; (2) Long term confidence attributed to pre-selection; (3) selection methods; (4) reliance on subjective analysis. The authors went further to identify some factors that influence client's choice of contractors/subcontractors in the United Kingdom's construction industry as contractor's organization, financial consideration, management resource, past experience, past performance, project specific and current workload. These factors were further broken down into thirty-one micro variables. Shen et al. (2004) developed the model adopted for awarding construction contracts on multi-criteria basis in China by presenting a list of competitiveness parameters. As an extension to the study by Shen et al. (2004), Tan et al. (2007) studied the contractor key competitiveness indicators adopted in the Hong Kong construction industry. It was found out that there is a list of indicators adopted for measuring contractors' competitiveness in the current Hong Kong construction market, and these key indicators have dominant influence on contractors' competitiveness. Luu and Sher (2005) investigated the construction tender selection of subcontractors in the developing countries and concluded that subcontract selection is hinged on some parameters which had earlier been highlighted. Waara and Brochner (2006) considered the price and non-price criteria for contractors' selection and concluded that non-price is more commonly used by clients consultants in their selection. The work of Ling et al. (2009) is also noted in this perspective.

In Nigeria, Ogunsanmi and Bamisile (1997) identified thirteen factors that can influence contractors'/subcontractors selection. Four additional factors among the identified criteria are: Size of project, aesthestics, provision of added services like finance and high management skill. Gidado (1996) studied the use of the alternative selection methods to implement projects and concluded that they are used without any apparent recognition of, or adjustment for the local situation. Ojo (2009) researched into the needs of clients for building projects and concluded that both public and private clients have the same need in Nigeria.

According to Sidwell (1984), client's/constructor's macro objectives have been agreed by construction researchers to be cost, time and quality. These generic objectives had however been broken down into micro objectives (factors). Although, the work of Holt et al. (1994) extensively delved into these micro criteria, their work was based on the client's selection of construction contractors in the United Kingdom. Also, the studies by Shen et al. (2004) and Tan et al. (2007) were based on contractors' competitiveness indicators in China and Hong Kong respectively. Though, Ojo (2009)'s work was targeted on a Nigerian scene, the work was on general identification of clients needs for building projects. The research on which this paper is based has therefore been premised on the fact that there is a collection of further selection criteria apart from the identified macro and micro objectives. If these criteria are identified and their premiums of importance determined, an objective quantitative framework could be facilitated. Hence, the prime purpose of this study is to present the findings of a survey of construction clients/contractors and rank the factors they consider in the selection of suitable subcontractors for project execution.

\section{Data Collection Method}

Primary data were collected through questionnaire survey. The study samples were randomly drawn from construction clients/contractors within the three major commercial nerve centres of Nigeria (Abuja, Lagos and Port Harcourt). Three sets of questionnaires were prepared on likert type scale of one to five to sample the opinion of three hierarchies of construction stakeholders (clients, main contractors and subcontractors) to determine the premium placed on some identified criteria that are being considered for subcontractors' selection for construction projects.

Out of the 100 questionnaires that were administered on each of the identified target respondents, 75, 70 and 72 questionnaires were filled and returned by client organizations, main contractors and subcontractors respectively. From the 75 questionnaires returned by the client organizations, 44 and 31 questionnaires were respectively from public clients and private clients. For the main contractors, 42 and 28 questionnaires were from public and privately owned projects. Research assistants were employed to distribute questionnaires and assist some of the respondents on site to interpret the questionnaires. The project types considered were residential, office, factory and commercial buildings. These were then categorized into two project costs: N10m - N500m and Above $\mathrm{N} 500 \mathrm{~m}$. The selection criteria was based on a 5- points scale, 1-"not important" to 5- "very important".

The total weight value (TWV) for each factor was computed by summing the product of the number of responses for each rating to a factor and the respective weight value. Thus expressed mathematically (Afon, 2009): 


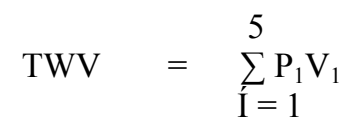

Where,

TWV $=$ total weight value

$\mathrm{P}_{\mathrm{i}} \quad$ = number of respondents that rated the factors.

$\mathrm{V}_{\mathrm{i}} \quad=$ weight assigned to a factor

The RIR to each factor was arrived at by dividing the TWV by the summation of the respondents to each of the five ratings of a factor.

This is expressed thus:

$\begin{aligned} & \text { RIR }= \frac{\text { TWV }}{5} \\ & \sum \mathrm{P}_{1} \\ & \mathrm{I}=1\end{aligned}$

Where,

TWV $\quad=$ Total weight value

RIR = Relative Index Ranking

This translates to:

$$
\begin{aligned}
& 5
\end{aligned}
$$

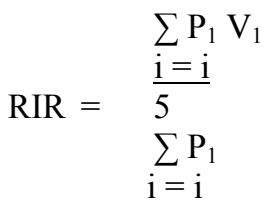

The closer the RIR of a factor to five, the higher the ranking. Seven macro factors were adopted for this study. They are: Subcontractors' organization, financial consideration, management resource, past experience, past performance, project facilitation and other related issues. These factors were further broken down into thirty-two micro variables which were fully described in the body of discussion.

\section{Results and Discussions}

In order to identify some of the influencing factors in the selection of construction subcontractors, questionnaires were administered to elicit data from client organizations and main contractors. Tables 1 and 2 therefore showed the responses from public client organizations and private clients respectively. Also, Tables 3 and 4 summarized the responses from main contractors on public projects and privately owned projects respectively.

The results of relative index rankings for public clients in the two categories of projects (Table 5) showed that public clients attached greatest premium to subcontractors' past experience $(\mathrm{RIR}=4.57)$. This is in the form of type of projects completed and the geographical spread. This is an indication that public clients are trying to be conscious of engaging subcontractors who had taken on a project that was too large for them to handle in the past. Second in the ranking, regardless of the project category, was subcontractors management resource $(\mathrm{RIR}=$ 4.05). This covers the sub-criteria such as qualification of owners, qualification with key persons, years with company, formal and informal training and overall management skill. In the words of Holt et al. (1994), good managerial skills are a scarce commodity, hence the importance of analyzing a contractor/subcontractor to discover his share of his previous human resource. Little wonders therefore that higher premium is attached to this factor. Other related issues ( $\mathrm{RIR}=3.81$ ) such as risk avoidance (time), risk avoidance (cost), period of the year in terms of weather, nature of contract, past relationship and the current workload were rated third in the ranking. It could be inferred that clients' fear of a subcontractor being unable to complete a project or become incommunicado might be responsible for this ranking.

In a similar vein, macro factors such as subcontractors' past performance $(\mathrm{RIR}=3.70)$, subcontractors project facilitation (RIR $=3.49$ ), subcontractors' organization (RIR $=3.20$ ) were ranked fourth, fifth and sixth respectively by the public clients. The variables considered under subcontractors' past performance include records of project delivery, project quality achieved as well as cost and time certainties. The variables considered under subcontractors' project facilitation are geographical spread, experience on similar construction, availability of plant resource and availability of key persons as well as their qualifications. For subcontractors' organization, the general particulars like size, age and image of company as well as health and safety policy were considered as micro factors in this regard. Of all the macro factors considered in the selection of subcontractors by public clients, financial consideration ( $\mathrm{RIR}=2.45$ ) was accorded the lowest premium in this ranking. This is so because this firm category is assumed not to be the main contractor for the project and there is every likelihood of mobilization fees (advance payment) for most of the government projects.

Similar views were shared by the private clients with their public counterparts in this regard, except with differing ranking values. Combining ranking values of the two client categories indicates the following: 
subcontractors' past experience $(\mathrm{RIR}=4.46)$; subcontractors' management resource $(\mathrm{RIR}=3.71)$; other related issues $(\mathrm{RIR}=3.46)$; subcontractors' past performance $(\mathrm{RIR}=3.25)$; subcontractors' project facilitation $(\mathrm{RIR}=$ 2.80). and financial consideration $(\mathrm{RIR}=2.13)$.

For the main contractors (Table 6), their ratings are not all that dissimilar from the views of the clients. Their ratings for the two categories of project size and type indicated the following: subcontractors' past experience $(\mathrm{RIR}=4.42)$; subcontractors' management resource $(\mathrm{RIR}=4.14)$; other relating issues regarding the subcontractors $(\mathrm{RIR}=4.06)$; subcontractors' past performance $(\mathrm{RIR}=3.90)$; subcontractors' project facilitation $(\mathrm{RIR}=3.65)$; subcontractors' organization $(\mathrm{RIR}=3.28)$ and subcontractors' financial consideration $(\mathrm{RIR}=$ 2.60). The results support the views of Holt et al. (1994) and Ojo (2009) that contractors'/subcontractors' past experience in terms of workload capacity and type of projects completed as well as project quality and cost are clients' important criteria in their selection bids.

\section{Conclusion}

An analysis of the factors influencing clients' and contractors' choice of construction subcontractors in Nigeria has been presented. Considering the overall ranking of the variables, the five highest ranks are: 1, subcontractors' past experience; 2, subcontractors' management resource in terms of formal and informal training; 3, other related issues such as past relationship and time of the year; 4, subcontractors' past performance; and 5, subcontractors' project facilitation in terms of geographical spread and availability of plant resource. It was also discovered that regardless of the project category, the clients' and contractors influencing attributes on the choice of suitable subcontractors for constructions projects are similar.

In view of the consensus of opinions in the selection of construction subcontractors by the clients and contractors, it was therefore concluded that more attention should be paid to the identified factors as a way of improving construction performance by these specialty contractors. Though, the work has identified a number of factors that are considered important in the selection of construction subcontractors, methods that properly recognize other criteria might be expected to make better selection. This can also be tested for other developing nations as well.

\section{References}

Afon, A.O. (2009). Residence and the Development Control Agency: A Perceptual Study of Two Local Planning Authorities, Ife Journal of Environmental Design and Management, O.A.O. Ile-Ife, Nigeria, 2(1), 44 - 54.

Beardworth, A.D., Keil, E.T., Bresnen M. and Bryma, A. (1988). Management Transience and Subcontracting: The Case of Construction Site, Journal of Management Studies, 26, 345 - 361.

Bresnen, M.J., Wray, K., Bryman, A., Beardsworth, A.D. Ford, J.R. and Keil, E.T. (1985). The Flexibility of Recruitment in the Construction Industry: Formalization or Recausation, Sociology, 19, 108-124.

Chan, A.P.C., Yung, E.H.K., Lam, P.T.I., Tam, C.M. and Cheung, S.O. (2001). Application of Delphi Method in Selection of Procurement Systems for Construction Projects, Construction Management and Economics, 19, 699-718.

Chang, C. and Ive, G. (2002). Rethinking the Multi-Attribute Utility Approach Based Procurement Route Selection Techniques, Construction Management and Economics, 20, 275-284.

Dissanayaka, S.M. and Kumaraswamy M.W. (1998). Comparing Contributors to Time and Cost Performance in Building Projects, Building and Environment, 34, 31-42.

Holt, G.D., Olomolaiye, P.O. and Harris, F.C. (1994). Factors Influencing U.K. Construction Clients' Choice of Contractor, Building and Environment, 29(2), 241-248.

Gidado, K. (1996). Political and Economic Development in Nigeria: What Procurement System is Suitable?. In Taylor, R.G. (ed) North meets South Developing Ideas. Proceedings of the Syposium of CIBW 92, Durban, South Africa, 400-409.

Kale, S. and Ardit, D. (2001). General Contractors' Relationships with Subcontractors: A Strategic Asset, Construction Management and Economics, 19, 541-549.

Kumaraswamy, M.M. (1999). Uncommon Sense and Artificial Intelligence for Re-engineering Procurement Systems, Proceedings of $2^{\text {nd }}$ International Conference on Construction Industry Development, Singapore, October, 173-187.

Lee, Y.W. (1991). Minimizing Loss on Subcontractors' Defective Performance, Unpublished B.Sc. Dissertation, School of Building and Estate Management, National University of Singapore, Singapore.

Ling, Y.Y. Low, S.P., Wang, S.Q., and Lim, H.H. (2009). Key Project Management Practices Affecting Singaporean Firms' Project Performance in China, International Journal of Project Management, 27(1), 59-71.

Luu, T. and Sher, W. (2005). Construction Tender Subcontract Selection Using the Case-based Reasoning, available at www.itcon.org/data/submissions/att/7795.content.00174.doc.

NEDO (1985). Thinking about Building, National Economic Development Office, HMSO, London. 
Ogunsanmi, O.E. and Bamisile A. (1997). Factors Affecting the Selection of Project Procurement Methods, Builders' Magazine, 7(1),11-15.

Oliver, C (1997). The Influence of Institutional and Track Environment Relationships on Organizational Performance: The Canadian Construction Industry, Journal of Management Studies, 34(1), 99-124.

Ojo, S.O. (2009). An identification of Client's Needs for Building Projects: A Nigerian Study, Ife Journal of Environmental Design and Management, O.A.U., Ile-Ife, Nigeria, 2(1), 20-30.

Sidwell, A.C. (1984). The Measurement of Success of Various Organizational Forms for Construction Projects. Proceedings of $4^{\text {th }}$ International Symposium on Organization and Management of Construction, CIB WGS, 1, 283-289.

Shen, L.Y., Li, Q.M., Drew, D., and Shen, Q.P. (2004). Awarding Construction Contracts on Multicriteria Basis in China, Journal of Construction Engineering and Management, 130(3), 385-393.

Tan, Y.T., Shen, L.Y., Yam, M.C.H., and Lo, A.A.C. (2007). Contractor Key Competitiveness Indicators (KCIs): a Hong Kong Study, Surveying and Built Environment, 18(2), 33-46.

Waara, F. and Brochner, J. (2006). Price and Non-price Criteria for Contractor Selection, Journal of Engineering and Management, 132(8), 797-804.

Table 1. Responses from Client Organizations (Public)

\begin{tabular}{|l|l|llllll|lllll|}
\hline S/N & Factors & \multicolumn{4}{|c|}{ N10m- N500m } & \multicolumn{4}{|l|}{ Above N500m } \\
& & 5 & 4 & 3 & 2 & 1 & & 5 & 4 & 2 & 1 \\
\hline 1 & Subcontractors' Organization & 8 & 9 & 14 & 7 & 6 & & 6 & 10 & 16 & 6 & 6 \\
2 & Financial Consideration & 3 & 8 & 10 & 12 & 11 & & 4 & 4 & 8 & 15 & 13 \\
3 & Management Resource & 20 & 14 & 4 & 3 & 3 & & 21 & 12 & 6 & 2 & 3 \\
4 & Past Experience & 28 & 15 & 1 & 0 & 0 & & 26 & 16 & 1 & 1 & 0 \\
5 & Past Performance & 15 & 13 & 7 & 6 & 3 & & 15 & 12 & 7 & 8 & 2 \\
6 & Project Facilitation & 11 & 17 & 6 & 6 & 4 & & 19 & 5 & 5 & 6 \\
7 & Other Related Issues & 19 & 10 & 4 & 7 & 4 & & 1711 & 6 & 6 & 4 \\
& & & & & & & & & & & \\
\hline
\end{tabular}

Table 2. Responses from Client Organizations (Private)

\begin{tabular}{|l|l|lllll|llllll|}
\hline S/N & Factors & \multicolumn{4}{|l|}{ N10m- N500m } & \multicolumn{4}{|l|}{ Above N500m } \\
& & 5 & 4 & 3 & 2 & 1 & 5 & 4 & 3 & 2 & 1 \\
\hline 1 & Subcontractors' Organization & 5 & 5 & 12 & 3 & 6 & 6 & 3 & 14 & 2 & 6 \\
2 & Financial Consideration & 1 & 3 & 9 & 3 & 15 & 2 & 3 & 8 & 5 & 12 \\
3 & Management Resource & 15 & 14 & 2 & 8 & 2 & & 13 & 7 & 3 & 4 & 4 \\
4 & Past Experience & 20 & 7 & 2 & 1 & 1 & & 21 & 8 & 0 & 2 & 0 \\
5 & Past Performance & 10 & 2 & 8 & 6 & 5 & & 11 & 4 & 7 & 5 & 4 \\
6 & Project Facilitation & 10 & 0 & 2 & 12 & 7 & & 8 & 4 & 1 & 9 & 9 \\
7 & Other Related Issues & 12 & 3 & 5 & 8 & 3 & & 11 & 5 & 3 & 6 & 6 \\
& & & & & & & & & & & \\
\hline
\end{tabular}

Table 3. Responses from Main Contractors (Private Projects)

\begin{tabular}{|l|l|llllll|lllll|}
\hline S/N & Factors & \multicolumn{4}{|c|}{ N10m- N500m } & \multicolumn{4}{|c|}{ Above N500m } \\
& & 5 & 4 & 3 & 2 & 1 & 5 & 4 & 3 & 2 & 1 \\
\hline 1 & Subcontractors' Organization & 6 & 14 & 3 & 1 & 4 & 5 & 13 & 4 & 4 & 2 \\
2 & Financial Consideration & 1 & 7 & 12 & 2 & 6 & 1 & 6 & 14 & 3 & 4 \\
3 & Management Resource & 17 & 7 & 0 & 0 & 4 & 15 & 8 & 1 & 1 & 3 \\
4 & Past Experience & 19 & 5 & 2 & 1 & 1 & & 20 & 4 & 3 & 0 & 1 \\
5 & Past Performance & 12 & 10 & 1 & 4 & 1 & 10 & 12 & 2 & 2 & 2 \\
6 & Project Facilitation & 10 & 10 & 5 & 1 & 2 & 7 & 14 & 4 & 2 & 1 \\
7 & Other Related Issues & 14 & 7 & 3 & 3 & 1 & 11 & 11 & 4 & 1 & 1 \\
& & & & & & & & & & & \\
\hline
\end{tabular}


Table 4. Responses from Main Contractors (Public Projects)

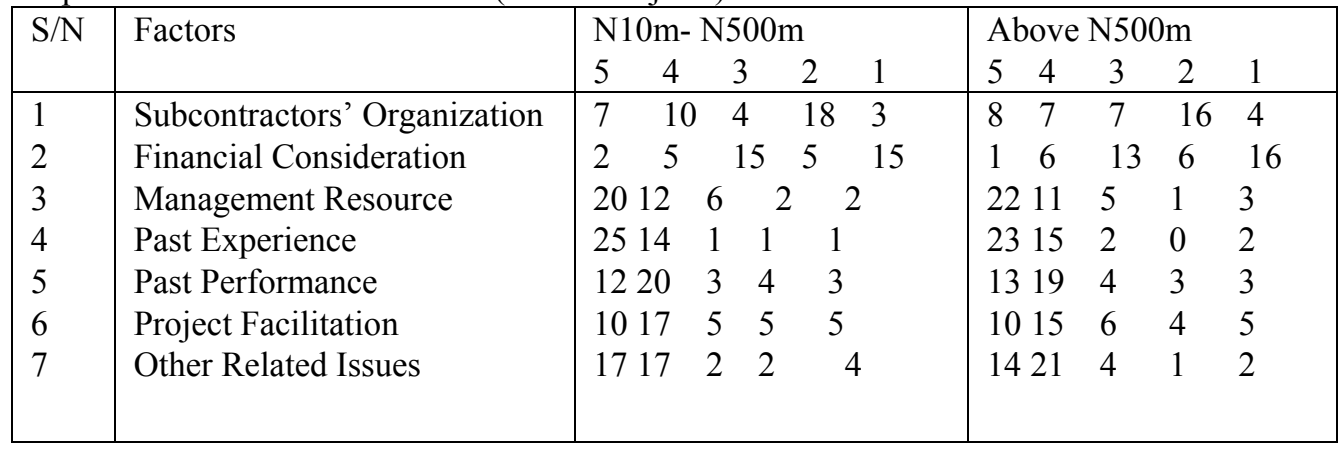

Table 5. Weighted Values and Relative Index Ranking for Client Organizations (Public \& Private)

\begin{tabular}{|c|c|c|c|c|c|c|c|c|c|c|c|c|c|}
\hline \multirow{2}{*}{$\begin{array}{l}\mathrm{S} / \mathrm{N} \\
\\
1\end{array}$} & \multirow{2}{*}{$\begin{array}{l}\text { Factor } \\
\text { Subcontractors' Organizations }\end{array}$} & \multicolumn{5}{|c|}{ 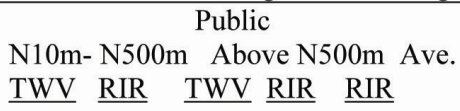 } & \multicolumn{5}{|c|}{\begin{tabular}{l}
\multicolumn{3}{c}{ Private } \\
N10m -N500m Above N500m Ave. \\
TWV RIR TWV RIR RIR
\end{tabular}} & \multirow{2}{*}{$\begin{array}{l}\text { All } \\
\text { Clients } \\
3.11\end{array}$} & \multirow{2}{*}{$\begin{array}{l}\text { Rank } \\
6^{\text {th }}\end{array}$} \\
\hline & & 145 & 3.30 & 136 & 3.09 & 3.20 & 93 & 3.00 & 94 & 3.03 & 3.02 & & \\
\hline 2 & Financial Consideration & 112 & 2.55 & 103 & 2.34 & 2.45 & 65 & 2.10 & 68 & 2.19 & 2.15 & 2.13 & $7^{\text {th }}$ \\
\hline 3 & Management Resource & 177 & 4.02 & 178 & 4.05 & 4.04 & 115 & 3.71 & 114 & 3.68 & 3.70 & 3.71 & $2^{\text {nd }}$ \\
\hline 4 & Past Experience & 203 & 4.61 & 199 & 4.52 & 4.57 & 137 & 4.42 & 141 & 4.55 & 4.49 & 4.46 & $1^{\text {st }}$ \\
\hline 5 & Past Performance & 163 & 3.71 & 162 & 3.68 & 3.70 & 99 & 3.19 & 106 & 3.42 & 3.31 & 3.25 & $4^{\text {th }}$ \\
\hline 6 & Project Facilitation & 155 & 3.52 & 152 & 3.46 & 3.49 & 87 & 2.81 & 86 & 2.77 & 2.79 & 2.80 & $5^{\text {th }}$ \\
\hline 7 & Other Related Issues & 172 & 3.91 & 163 & 3.71 & 3.81 & 106 & 3.42 & 111 & 3.58 & 3.50 & 3.46 & $3^{\text {rd }}$ \\
\hline
\end{tabular}

Table 6. Weighted Values and Relative Index Ranking for Main Contractors (Public \& Private)

\begin{tabular}{|c|c|c|c|c|c|c|c|c|c|c|c|c|c|}
\hline $\mathrm{S} / \mathrm{N}$ & Factor & $\begin{array}{l}\text { N101 } \\
\text { TW }\end{array}$ & $\begin{array}{l}n-\mathrm{N} 5 \\
- \text { RIF } \\
\end{array}$ & $\begin{array}{r}\mathrm{Pu} \\
\mathrm{m} \quad \mathrm{A} \\
\mathrm{TW} \\
\end{array}$ & $\begin{array}{l}\text { lic } \\
\text { bove N } \\
\text { V RIR }\end{array}$ & $\begin{array}{l}500 \mathrm{~m} \text { Ave. } \\
\underline{\text { RIR }}\end{array}$ & $\begin{array}{l}\text { N10n } \\
\text { TWV }\end{array}$ & RIR & $\begin{array}{r}\text { Priv } \\
\text { m Al } \\
\text { TW }\end{array}$ & $\begin{array}{l}\text { vate } \\
\text { bove N } \\
\text { V RIR }\end{array}$ & $\begin{array}{l}\text { N500m Ave. } \\
\text { R RIR }\end{array}$ & $\begin{array}{l}\text { All } \\
\text { Contractor }\end{array}$ & Rank \\
\hline 1 & Subcontractors' Organizations & 124 & 2.95 & 125 & 2.98 & 2.97 & 101 & 3.61 & 99 & 3.54 & 3.58 & 3.28 & $6^{\text {th }}$ \\
\hline 2 & Financial Consideration & 100 & 2.38 & 96 & 2.29 & 2.34 & 79 & 2.82 & 81 & 2.89 & 2.86 & 2.60 & $7^{\text {th }}$ \\
\hline 3 & Management Resource & 172 & 4.09 & 174 & 4.14 & 4.12 & 117 & 4.18 & 115 & 4.11 & 4.15 & 4.14 & $2^{\text {nd }}$ \\
\hline 4 & Past Experience & 187 & 4.45 & 179 & 4.26 & 4.36 & 124 & 4.43 & 126 & 4.50 & 4.47 & 4.42 & $1^{\text {st }}$ \\
\hline 5 & Past Performance & 160 & 3.81 & 162 & 3.85 & 3.83 & 112 & 4.00 & 110 & 3.93 & 3.97 & 3.90 & $4^{\text {th }}$ \\
\hline 6 & Project Facilitation & 148 & 3.52 & 141 & 3.36 & 3.44 & 109 & 3.89 & 107 & 3.82 & 3.86 & 3.65 & $5^{\text {th }}$ \\
\hline 7 & Other Related Issues & 167 & 3.98 & 170 & 4.05 & 4.02 & 115 & 4.11 & 114 & 4.07 & 4.09 & 4.06 & $3^{\text {rd }}$ \\
\hline
\end{tabular}

